\title{
THE EPISTEMOLOGICAL CHALLENGE OF KIERKEGAARD'S TRUTH IS SUBJECTIVITY PRINCIPLE
}

\begin{abstract}
Kierkegaard rejects the modern concept of objective knowledge and focuses instead on subjectivity, defined as 'inwardness' and 'passion' in determining what might be called 'relevant' or 'existential' truth. Truth should thus be understood as an objective uncertainty appropriated passionately by the inward reflective experience of love and faith of the self. Such 'Kierkegaardian' primacy of epistemology implies that one must first discover the truth about morality and life, in order to try to live out that truth. The proud pursuit of objectivity without a recognition of human limitations, and the dimension of subjectivity in the process, has proved to be a dead end that emits the stench of manipulation, loss of human dignity, and finally nihilism. Understanding the limits of reason will help us avoid the pitfall of 'scientism'.
\end{abstract}

Keywords: Soren Kierkegaard, epistemology, truth, reason, subjectivity, science, faith.

\section{Introduction}

Kierkegaard does not accept typical, modern epistemology's concept of moral and religious knowledge, wherein philosophers focus on objective justification (evidence) for our beliefs. We continue to see this futile emphasis being used against an everincreasing threat of nihilism and moral relativism today. However, the solution of summoning more and more intellectual, rational support for whatever ethical principles we wish to promote is not working and will not work. Similarly, we tend to think that it is the lack of objective evidence that causes the decline in religious faith, whether individually or collectively. According to Evans, Kierkegaard poses a permeating challenge here: "If our grasp of moral knowledge is less secure, it may be because we have become less moral. If religious faith has declined, it is not because we are now more rational and demand more evidence than people did in earlier times, but because we lack the imaginative and emotional capacities to understand the power of religious beliefs" [1]. Not the evidence itself, but rather the character of the knower should be under primary scrutiny. This, however, is difficult to promote because humans prefer the position of 'detached observers' (or, supposedly, 'objective scientists') to that of 'engaged participants' who, by their own attitudes and actions, influence the very process of knowing and thus the results of their scrutiny. Søren Kierkegaard serves as an inspiration and a valuable resource in coping with the intricately connected challenges of personal ethics and epistemology.

\section{The Character of the Knower and the 'Truth is Subjectivity' Principle}

The Kierkegaardian statement 'truth is subjectivity' [2] can mean a lot of different things [3]. Kierkegaard is highly suspicious of the one-sided focus on objective reflection for it leads into existential indifference (the loss of the subject and subjectivity). In his Concluding Unscientific Postscript he argues that "[t] he way of objective reflection turns the subjective individual into something accidental and thereby turns existence into an indifferent, vanishing something. The way to the objective truth goes away from the subject, and while the subject and subjectivity become indifferent, the truth also becomes indifferent, and that is precisely its objective validity, because the interest, just like the decision, is subjectivity" [2, p. 193]. Truth should rather be understood as an objective uncertainty appropriated passionately by the inward reflective experience of love and faith of the self. This is what Kierkegaard considers to be the highest truth a person can attain [4, p. 158]. The reading of Kierkegaard that might prove most useful on this subject understands this statement in the sense that "[t]he quest for truth, at least the truth about the most important things, cannot be divorced from the quest to become the kind of person we need to become. The primacy of epistemology implies that we must first discover the truth about morality and life, and then perhaps we can try to live out that truth. Perhaps it is true that we can only acquire the truth as part of the process whereby we learn to live out the truth" [1, p. 26-7]. One of the reasons why this tends to be so difficult for Christians to practice might be the nature of the process - trying

\footnotetext{
* Michal Valco, Katarina Valcova

Department of Religious Studies, Faculty of Humanities, University of Zilina, Slovakia,

E-mail: michal.valco@fhv.uniza.sk
} 
to live out the truth of Christ, the crucified Messiah. Luther was one of the few medieval theologians to depict the Christians' experience of suffering as a key hermeneutic component in understanding Christ's message. Hinkson is right to argue that for both, "Kierkegaard and Luther alike, suffering and discipleship remove the theology of the cross from the realm of mere cognitive theory (and hence from the danger of degenerating into a theology of glory) to the personally costly realm of praxis" [5].

This brings us to what some authors have come to call the principle of 'experiential epistemology' [6]. A strong emphasis on memory, logical argumentation and confessional purity of theological education (and thus on the objective aspects of religious faith) does not reflect the new dynamics of our culture. It omits, among other things, the focus on intuition, on emotional processing of events, and the intensity of experience. In fact, it does not reflect the complexity of the process of learning. This trend is further reinforced by a growing suspicion of all metanarratives - whether they are religious, political, or philosophical in the fragmented world of Western post-modernism. Kierkegaard should rightly be considered a prophet in this respect. The neglect of the subject and his inner world results in ambitious projects of human ideologies at the expense of the individual. The proud pursuit of objectivity without a recognition of human limitations, and the dimension of subjectivity in the process, has proved to be a dead end that emits the stench of manipulation, loss of human dignity, and finally nihilism. Harries is right to remind us of the necessity to acknowledge the limitations of our epistemological and scientific endeavors: "to understand that what we experience is only an appearance, bound by a particular perspective, is to be already on the road towards a more adequate, and that means here first of all less perspective-bound and in this sense freer understanding. The pursuit of truth demands a movement of self-transcendence that, by leading us to understand subjective appearance for what it is, opens a path towards a more adequate, more objective understanding" [4, p. 161]. Harries doesn't suggest that the way to go is to get lost in mere subjective fancies. On the contrary, "[t]he pursuit of truth demands objectivity. But.. truth here is not thought in relation to God. When we attempt to do so we discover ourselves to be in the wrong" [4, p. 161].

\section{Limits of Human Reason - Implications for Epistemology}

In addition to the welcomed emphasis on the nature and the importance of the knower in the process of acquiring true knowledge, Kierkegaard reminds us of the limits of human reason. It should be no surprise to finite, mortal creatures that "there are limits to human reason, limits that make it necessary for humans to respond in faith to a divine revelation if we are to reach the truth about ourselves" [1, p. 31]. There are some truths which the human mind (being naturally limited in both the scope and nature of knowledge) cannot comprehend. The best and most important example that Kierkegaard points out is the phenomenon of Incarnation (John 1:1-3.14). It would certainly be unfounded to blame Kierkegaard of irrationalism on this point. After all, the human mind as a 'conscious reality' remains essentially an impenetrable mystery to scientists. Both philosophy and the cognitive sciences have begun an ambitious enterprise: "to get beyond the confines of our individual minds, with their personal histories and idiosyncrasies, to grasp how reality is in itself, right down to its ultimate principles" [7] so that we (thinking humans) can "bring the world up close and gaze into its inner constitution, so that everything falls into place under the bright light of universal reason [emphasis added]" [7]. Yet there is a remaining sense of awe and mystery, or at least there should be. For just like the separation of spirit (that is, conscious mind with its conscious will) remains a mystery in our understanding of evolution, our minds are not able to comprehend the mystery of the uniting of spirit with matter in the event of the 'Word becoming Flesh,' personified in Jesus from Nazareth [8]. Philosophers, scientists, as well as theologians should rather humbly concede that neither science nor religion can claim to give a total account of reality. Science, philosophy, and theology rather operate in different dimensions, using different perspectives to answer the same or similar questions, as McGrath suggests in his Science and Religion: A New Introduction. McGrath indicates: "Science does not answer every question that we might have about the world. Neither does religion. Yet taken together they can offer a stereoscopic view of reality denied to those who limit themselves to one discipline's perspective on things. The science and religion dialogue allows us to appreciate the distinct identities, strengths, and limits of each conversation partner. It also offers us a deeper understanding of things than either religion or science could offer unaided" [9].

\section{Distinguishing 'Science' from 'Scientism'}

Thus there are good reasons to believe that the human society would be better off if it resisted the tempting delusions of 'scientism' and treated science for what it actually is: a specific, distinct culture with its own methodology, presupposition, and values [10]. Much like theology, science is "a network of material practices, built environments (including laboratories, instrumentation, etc.), traditions of apprenticeship, and learned rituals that emerged over time, in particular configurations, in different places” [10, p. 5]. So, epistemologically speaking, science - like ethics, as well as 'Kierkegaardian' faith - takes place within a complex human tradition. If we agree with the previous conclusion that "we can only acquire the truth as part of the process whereby we learn to live out the truth" [1, p. 26-7] then it follows that in order to acquire new scientific knowledge, the scientists themselves 'create their own phenomena' (so to speak) and are changed in the process of a disciplined study of 
nature: "While science seeks to be disciplined by nature, there is also a sense in which science creates its own phenomena. It constitutes its world through experimental performance which is a learned performance requiring its own set of virtues and skills, deft employment of instrumentation, and a kind of 'knowhow' that is not theoretical, and perhaps not even 'intellectual' [10, p. 6]. This leads us to reject the unscientific assumptions of metaphysical naturalism - which is, in fact, not primarily a product of the $18^{\text {th }}$ and $19^{\text {th }}$ centuries but rather of the $20^{\text {th }}$ century [11]. Such assumptions are really nothing but unfounded, metaphysical presuppositions at variance with the legitimate methodological naturalism of science [12]. What we are thus dealing with here under the disguise of science, is a distinct, materialistic philosophy of reality, promoted dangerously as the only viable - that is, 'objective, scientific' - account of reality. A hidden ideology is thereby portrayed as respectable science, causing people to lay down their defenses and to readily accept everything such 'science' has to offer.

Our Central and Eastern European societies have had a direct experience with a radically militant strand of such metaphysical naturalism in the form of the atheistic materialism of Communist ideology - with grave socio-political, economic, and especially moral consequences [13]. Severed from faith, the pragmatic reason of the ideologists had no convincing answer to the questions: 'what constitutes moral action?', and 'why should I be moral?' This is what already in the 18th century Kant suspected in his doctrine of radical evil [4, p. 167]. Our totalitarian experience validates Harris' thesis that '[t]here is no argument that can make an evil person embrace the good, no good argument, e. g., that will force someone who finds the claim that we should strive to maximize pleasure and minimize pain in our own case quite persuasive, but sees no good reason to extend that principle to all human beings or perhaps even further, to change his mind. That would require a change of heart. Ethics presupposes faith in some power that calls us to that respect of others and their rights that found expression in Kant's categorical imperative. In that sense when we dig into the foundations of ethics we will inevitably hit sooner or later on religious ground" [4, p. 167].

\section{Conclusion}

Faith and reason, theology and philosophy, should instead be seen as different ways of organizing affects, both being reconceived as assemblages. If we follow the lead of Adkins and Hinlicky in their Rethinking Philosophy and Theology with Deleuze: A New Cartography, perhaps we can constructively reinvent the relation between reason (philosophy) and faith (theology) in a way that allows their proper distinction while differentiating various domains of thought on the bases of what they create [14]. What we see in Kierkegaard is an abrupt departure from the European metaphysical tradition which favored the noetic certainty of knowledge. For Kierkegaard, truth is more than a noetic, objective category, accessible to intellectual inquiry by a thinking subject. There must be a deeper, existential basis, related to the deepest aspirations and, yes, fears and doubts of the individual - a desire permeated by passion. The truth cannot be meaningful and relevant without this 'subjective desire,' whose doubt is the beginning of the highest form of existence. This leads us beyond delineating the boundaries of the unknown (and the unknowable) in the negative form, all the way forward to the positive question: 'who am I and what am I to do?'.

\section{References}

[1] EVANS, S.: Why Kierkegaard Still Matters - and Matters to Me, Why Kierkegaard Matters: A Festschrift in Honor of Robert L. Perkins, Robert L. Perkins, Marc Alan Jolley \& Edmon L. Rowell (eds.), Mercer University Press, 2010, p. 26.

[2] KIERKEGAARD, S.: Concluding Unscientific Postscript to Philosophical Fragments: A Mimical-Pathetical-Dialectical Compilation, An Existential Contribution, vol. 1, Trans. Howard V. Hong and Edna H. Hong, Princeton : Princeton University Press, 1992, pp. 189ff.

[3] KRALIK, R.: Kierkegaad's Abraham (in Slovak), Ljubljana: KUD Apokalipsa, 2013, p. 50, Kralik underscores the importance of this principle in battling what he calls 'formal Christianity.'

[4] HARRIES, K.: Between Nihilism and Faith: A Commentary on Either/Or, Berlin - New York : Walter deGruyter, 2010, p. 158.

[5] HINKSON, C.: Luther and Kierkegaard - Theologians of the Cross, p. 45, Intern. J. of Systematic Theology, vol. 3, No. 1, March 2001, 27-45.

[6] VALCO, M.: Cultural Challenges and Future hopes of Christian Church in Slovakia (in Slovak), The Service of Renewal. A Scientific Collection, Bratislava : Comenius University in Bratislava, 2010, 116-123.

[7] MCGINN, C.: The Mysterious Flame: Conscious Minds in a Material World, New York : Basic Books, 1999, p. 206.

[8] John 1:1-3.14, The Holy Bible - New International Version ${ }^{\circledR}$. NIV®. Copyright $@$ C 1973, 1978 and 1984 by International Bible Society.

[9] MCGRATH, A.: Science and Religion: A New Introduction, 2nd edition, Wiley-Blackwell, 2010, p. 2. Quoting Jay Gould's incisive essay on the subject, 'Nonnormal Nature,' McGrath points out the inability of scientific endeavor to discern and define that 


\section{COMMNICOIIIONS}

which is universally good: "Our failure to discern a universal good does not record any lack of insight or ingenuity, but merely demonstrates that nature contains no moral messages framed in human terms. Morality is a subject for philosophers, theologians, students of the humanities, indeed for all thinking people. The answers will not be read passively from nature; they do not, and cannot, arise from the data of science." Ibid., p. 3; original source: GOULD, S. J.: Hen's Teeth and Horse's Toes: Further Reflections in Natural History, New York: W. W. Norton, 1994, p. 42.

[10] SMITH, J. K. A.: Science and Religion Take Practice: Engaging Science as Culture, Perspectives on Science and Christian Faith, vol. 65, No. 1 (March 2013): 3-9. Much of the modern conflict between science and theology can be attributed to the fact that "the theology/science conversation has tended to ignore the fact that science is a cultural institution. By a 'cultural institution,' I mean, first of all, an institution that is a product of human making, a contingent product of poiesis. Culture is the unfolding of potentialities that are latent or implicit in 'nature,' as it were." Ibid., p. 4.

[11] GREGORY, B. S.: No Room for God? History, Science, Metaphysics, and the Study of Religion, History and Theory, vol. 47, 2008, 495-519. This view has come to be known as "metaphysical naturalism."

[12] BISHOP, R. C.: God and Methodological Naturalism in the Scientific Revolution and Beyond, Perspectives on Science and Christian Faith, vol. 65, No. 1, March 2013, 10-23.

[13] VALCO, M.: Setting the Stage for a Meaningful Engagement: The Need for a Competent Public Theology in the Post-Communist Context of Slovakia, p. 226, 2012, Christian Churches in Post-Communist Slovakia: Current Challenges and Opportunities, 185256.

[14] ADKINS, B., HINLICKY, P.: Rethinking Philosophy and Theology with Deleuze, A New Cartography : London : New Delhi : New York : Sydney : Bloomsbury, 2013, 214-216. It might be worth considering what kind of new questions, if any, arise from this (that is, Adkins' and Hinlicky's) juxtapositioning of Deleuze and Christian theology on the same plane of immanence. 